\title{
PROBLEM PSIKOSPIRITUAL LANSIA DAN SOLUSINYA DENGAN BIMBINGAN PENYULUHAN ISLAM (Studi Kasus Balai Pelayanan Sosial Cepiring Kendal)
}

\author{
Mei Fitriani \\ Penyuluh Agama Tetap Non PNS Kabupaten Pemalang \\ Email:meyfitrianie@gmail.com
}

\begin{abstract}
Elderly is the stage of human development that has decreased both physical and psychological. Various causes of the decline in the elderly did not carry out a social function in the community maximally. The decline in these conditions also affects the elderly who turned psych spiritual problems with the theory that a person's spiritual will increase when entering elderly age. Islamic Guidance and Counseling is one way that can be given to treat variety problems of the elderly psych spiritual, such as loss of meaning in life, easy emotion, and alienation with their selves. Hall of social services of Kendal Cepiring is one of the center that provide guidance and counseling services for the elderly fostered Islam. The service is able to deliver the elderly to find meaning in life, be diligent in worship and control self-emotion.
\end{abstract}

Kondisi udzur sebagaimana digambarkan dalam Qur'an surat Ar-Rum ayat 54, menyebutkan tentang penurunan yang menggerogoti lanjut usia. Penurunan tersebut terdiri dari fisik dan psikis yang menyebabkan lansia tidak melaksanakan fungsi sosial didalam masyarakat secara maksimal. Penurunan kondisi pada lansia tersebut juga berpengaruh terhadap psikospiritual lansia yang berbalik dengan teori yang menyebutkan spiritual seseorang akan meningkat saat memasuki usia lanjut. Balai pelayanan merupakan tempat yang tepat bagi masyarakat dan lansia yang tidak mampu mengatasi masalah-masalah pada lansia terutama spirtitual. Adanya penyuluh agama Islam di balai pelayanan diharapkan mampu membimbing lansia secara maksimal yaitu sebagai motivator, stabilitator dan direktif. Hal itu dapat diwujudkan dalam berbagai bentuk kegiatan lansia di balai pelayanan yaitu bimbingan keagamaan.

Keywords: Elderly, psych spiritual, guidance, counseling 


\section{A. Pendahuluan}

Proses penuaan (aging process) dalam perjalanan hidup manusia merupakan suatu hal yang wajar, dan akan dialami oleh semua orang yang dikaruniai umur panjang. Menurut teori perkembangan manusia di mulai dari masa bayi, anak, remaja, dewasa, tua dan akhirnya masuk pada fase usia lanjut dengan umur 60 tahun dan di atas 60 tahun. ${ }^{1}$

Seiring berjalannya waktu, proses penuaan tersebut terjadi secara natural. Masa penuaan inilah yang kemudian banyak terjadi penurunanpenurunan dilihat dari aspek fisik dan psikologis. Penurunan pada lanjut usia (lansia) tercantum jelas dalam Al-Quran:

Artinya: "Allah, Dialah yang menciptakan kamu dari keadaan lemah, kemudian Dia menjadikan kamu sesudah keadaan lemah itu menjadi kuat, kemudian Dia menjadikan kamu sesudah kuat itu lemah kembali dan beruban. Dan menciptakan apa yang dikehendaki-Nya dan Dialah yang maha mengetahui lagi maha kuasa" (Qs.Ar-Rum: 54)²

Kondisi yang sudah udzur sebagaimana digambarkan ayat di atas akan menyebab kan penurunan yang menggerogoti lanjut usia. Kelemahan biologis terlihat mempengaruhi keberadaan manusia usia lanjut. ${ }^{3}$ Penurunan pada fisik bisaanya ditandai dengan bahu membungkuk dan tampak mengecil, perut membesar dan tampak membuncit, pinggul tampak menggendor dan tampak lebih besar, garis pinggang melebar, payudara pada wanita akan mengendor, hidung menjulur lemas, bentuk mulut akan berubah karena hilangnya gigi, mata kelihatan pudar, dagu berlipat dua atau tiga, kulit berkerut dan kering, rambut menipis dan menjadi putih. ${ }^{4}$

Sedangkan secara psikologis, ciri-ciri penurunannya adalah kesepian, duka cita (Breavement), depresi, gangguan cemas, parafrenia, dan sindroma diogenes. ${ }^{5}$ Banyaknya penurunan-penurunan ini kemudian masyarakat menganggap lansia itu lemah dan membebankan. ${ }^{6}$ Akhirnya tidak sedikit diantara mereka membawa bapak atau ibunya yang lanjut usia ke panti

1 Mujahidullah, Khalid, Keperawatan Gereatrik, (Celeban Timur : Pustaka Pelajar, 2012), hal 1

2 Kementrian Agama, 2010: 370

3 Jalaluddin, Psikologi Agama, (Jakarta : PT RajaGrafindo Persada, 1996), hal 101

${ }^{4}$ Hurlock, Elizabeth B, Psikologi Perkembangan, (Jakarta: Erlangga, 1980), hal 388

${ }^{5}$ Hurlock, Elizabeth B, Psikologi Perkembangan, (Jakarta: Erlangga, 1980), hal 388

6Jalaluddin, Psikologi Agama, (Jakarta : PT RajaGrafindo Persada, 1996), hal 97 
jompo atau panti wredha, baik yang berada dibawah naungan dinas sosial maupun swasta. ${ }^{7}$

Ditegaskan pula dalam UU No 13 tahun 1998 pasal 5 ayat 1 bahwa lanjut usia mempunyai hak yang sama dalam kehidupan bemasyarakat, berbangsa, dan bernegara. ${ }^{8}$ Artinya disamping lanjut usia diberi hak untuk bermasyarakat, undang-undang tersebut memberi penjelasan kepada masyarakat agar tidak lagi beranggapan bahwa lansia itu membebankan, walaupun masih ada yang menitipkan para lansia ke balai pelayanan karena dilihat dari faktor lain misal ekonomi yang begitu rendah.

Begitu pula menurut hasil observasi tertanggal 6 agustus 2015, lansia yang berada di Balai Pelayanan Sosial (Bapelsos) Cepiring Kendal adalah mereka keluarga yang terlantar. Terlantar di sini memiliki dua arti, yang pertama yaitu terlantar karena dijalan dan yang kedua terlantar karena keluarga tidak mampu merawat lagi. ${ }^{9}$ Balai Pelayanan Sosial Cepiring Kendal tetap membuka kepada siapa saja yang tidak mampu merawat keluarganya yang sudah lanjut usia. Balai ini sebagai pelaksana teknis Dinas Sosial Jawa Tengah, secara operasional menyelenggarakan pelayanan kesejahteraan sosial yang bertanggungjawab membantu golongan lanjut usia yang tidak mampu agar dapat menikmati hari tuanya. ${ }^{10}$

Lansia yang berada di balai sangat beragam, kebanyakan dari mereka merasa sedih dan kesepian, sedikit diantara mereka yang merasa senang dan bahagia karena jauh dari keluarganya. Berbagai upaya kegiatan dilakukan oleh balai dalam rangka memberikan aktifitas kepada para lansia agar tetap bersemangat dan termotivasi dalam menjalani kehidupan. Termasuk bimbingan keagamaan yang dilakukan setiap hari Selasa dan Kamis pukul 14.00 WIB, dan Kamis malam pukul 18.00 WIB. Materi setiap selasa dan kamis yaitu bimbingan agama oleh instruktur dari Departemen Agama, dan instruktur dari tokoh masyarakat, serta malam jum'at yaitu istighosah dari Modin daerah. ${ }^{11}$

Tujuan dari pelaksanaan bimbingan agama tersebut adalah untuk memberi motivasi, mengingatkan agar selalu tekun beribadah, dan mengingatkan agar selalu bertakwa kepada Allah SWT.12 Pada umumnya balai pelayanan sosial membangun kemitraan dengan pihak lain dalam

\footnotetext{
7 Observasi tentang latar belakang para lansia di Balai Pelayanan Sosial Cepiring Kendal tanggal 6 agustus 2015

8 Undang-Undang No 13 tahun 1998

9 Peraturan Gubernur No 53 tahun 2013

10 http://bapelsoscepiring.blogspot.co.id/

11 Observasi 6 agustus 2015

12 Wawancara dengan bapak Nurudhin tanggal 13 agustus 2015
} 
upaya memenuhi serangkaian kegiatan pelayanan sosial termasuk bimbingan penyuluhan Islam, baik itu dari penyuluh agama, Kementrian Agama, Kyai atau Ustad, maupun perangkat desa ataupun Modin kelurahan. Hal ini terjadi karena balai tidak memiliki tenaga yang kompeten dalam bidang bimbingan penyuluhan Islam.

Meskipun pelaksanaan bimbingan agama telah dilaksanakan secara rutin, menurut pandangan penulis masalah tersebut belum dapat diselesaikan. Kegiatan penyuluhan yang dilakukan oleh penyuluh lebih banyak mengandalkan metode ceramah dan menyampaikan materi secara monoton. Kemudian belum adanya evaluasi yang dilakukan dari pekerja sosial dan penyuluh agama merupakan kelemahan dari tugas pemberian bimbingan keagamaan. Evaluasi yang dirasa sangat penting, harusnya dilakukan meski hanya satu bulan sekali dengan tujuan mengetahui apa saja kekurangan yang diberikan dalam memberikan pelayanan kepada lansia, sehingga kesejahteraan lansia di akhir hidupnya menjadi lebih jelas. Penyuluh agama juga masih sangat minim melakukan analisis terhadap permasalahan mengapa lansia tidak menjalalankan ibadah secara teratur, tidak mengaji, dan pasrah seperti itu. Ini terjadi karena tidak adanya evaluasi.

Berdasarkan argumentasi tersebut, meneliti tentang masalah keagamaan pada lansia di Balai Pelayanan Sosial Cepiring Kendal merupakan suatu hal yang menarik. Penulisan ini diharapkan akan menemukan suatu rumusan bimbingan yang digunakan dalam mengatasi problem psikospiritual yang real dialami lansia. Rumusan bimbingan dimaksud bukan berarti merubah secara total bimbingan yang telah ada sebelumnya, namun berusaha mengembangkan bimbingan yang telah ada di Bapelsos Cepiring Kendal. Sehingga memungkinkan lansia lebih bersemangat dalam menjalani kehidupan untuk mencapai kesejahteraan hidupnya. Berbagai pengembangan konsep bimbingan bertujuan untuk mengantisipasi trend (kecenderungan) berkembangnya problematika yang semakin kompleks. ${ }^{13}$ Dari itulah penulis kemudian berusaha mengangat artikel yang berjudul Problem Psikispiritual Lansia dan Solusinya dengan Bimbingan Penyuluhan Islam

13 Yusuf LN, Syamsu. Mental Hygiene Pengembangan Kesehatan Mental dalam Kajian Psikologi dan Agama. (Bandung : Pustaka Bani Quraisy.2004) (Yusuf,2004:179). 


\section{B. Problem Psikospiritual Lanjut Usia (Lansia)}

\section{Pengertian Problem Psikologi}

Psikologi berasal dari kata "psyche" yang berarti jiwa dan "logos" yang berarti ilmu, jiwa sering dihubungkan dengan masalah mistik atau kebatinan dan kerohaniaan, namun para sarjana lebih suka menggunakan istilah psikologi. Makna "psyche" adalah jiwa namun objek utama psikologi bukanlah jiwa, karena jiwa tidak dapat dipelajari secara ilmiah. Objek psikologi adalah tingkah laku manusia atau gejala kejiwaan. ${ }^{14}$

Kemudian dapat penulis pahami bahwa pengertian problem psikologi adalah suatu persoalan perilaku, perbuatan atau proses-proses mental dan alam pikiran manusia yang menuntut adanya suatu pemecahan karena keadaan yang tidak sesuai.

\section{Pengertian problem spiritual}

Spiritual adalah potensi yang ada dalam diri manusia yang berhubungan dengan aspek ajaran agama dan keyakinannya. Pengertian luas mengenai spiritual mencakup pengetahuan, pemahaman dan pengalaman agama seseorang. ${ }^{15}$ Pengertian yang dijelaskan oleh BKKBN, spiritual adalah suatu keyakinan yang percaya kepada kekuatan yang maha kuasa (Tuhan) diatas segala kemampuan manusia. ${ }^{16}$

Menurut Webster ${ }^{17}$, spiritual berasal dari kata "spiritus" yang artinya nafas dan kata kerjanya "spirare" yang berarti untuk bernafas. Spiritualitas merupakan kebangkitan atau pencerahan diri dalam mencapai tujuan dan makna hidup. Menurut Hasan ${ }^{18}$, spiritualitas merupakan bagian esensial dari keseluruhan kesehatan dan kesejahteraan seseorang dalam pengertian yang lebih luas spirit dapat diartikan; 1. Kekuatan kosmis yang memberi kekuatan kepada manusia (yunani kuno); 2. Mahluk immaterial seperti peri, hantu dan sebagainya; 3. Sifat kesadaran, kemauan, dan kepandaian dalam alam menyeluruh; 4. Jiwa luhur dalam alam yang bersifat mengetahui semuanya, mempunyai akhlak tinggi, menguasai keindahaan,

\footnotetext{
14 (Ahyadi, 2001: 23).

15 Hidayanti, Ema, Model Bimbingan Mental Spiritual. (Semarang: LP2M IAIN Walisongo, 2014), hal 25

16 Direktorat Bina Ketahanan Keluarga Besar Lansia, 2012: 3

17 Hasan, Aliyah Purwakania, Psikologi Perkembangan Islami. Jakarta: PT Rajagrafindo Persada, 2006), hal: 288

18 (Jalaludin, 2010:330)
} 
dan abadi; 5. Dalam agama mendekati kesadaran agama; 6. Hal yang terkandung minuman keras dan menyebabkan mabuk.

Konsep spiritual memiliki arti yang berbeda dengan konsep religius. Banyak yang tidak dapat membedakan kedua konsep tersebut karena menemui kesulitan dalam memahami keduanya. Kedua hal tersebut memang sering digunakan secara bersamaan dan saling berhubungan satu sama lain. Konsep religius bisaanya berkaitan dengan pelaksanaan suatu kegiatan atau proses melakukan suatu tindakan. Konsep religius merupakan suatu sistem penyatuan yang spesifik mengenai praktik yang berkaitan bentuk ibadah tertentu.

Dengan demikian religi adalah proses pelaksanaan suatu kegiatan ibadah yang berkaitan dengan keyakinan tertentu. Hal tersebut dilakukan dengan tujuan untuk menunjukkan spiritualitas diri mereka. Sedangkan spiritual memiliki konsep yang lebih umum mengenai keyakinan seseorang. Keyakinan dan kepercayaan akan Tuhan bisaanya dikaitkan dengan istilah agama, konsep yang dipahami tentang spiritual dan religious seseorang merupakan bagian dari spiritual, jika spiritual seseorang tinggi maka religus seseorang cenderung lebih baik namun ketika religius seseorang tinggi belum berarti spiritual seseorang tinggi dilihat dari beberapa tingkah laku yang sesuai dengan ajaran agama. Menurut Danah Zohar dan Ian Marshall, spiritual merupakan bagian dari kecerdasan intelektual dan kecerdasan emosional, mereka menyebutkan bahwa SQ (Spiritual Quotion) tidak ada hubungannya dengan agama. Meskipun seseorang dapat mengekspesikan SQ melalui agama ${ }^{19}$

Di dunia ini, banyak agama yang dianut oleh masyarakat sebagai wujud kepercayaan mereka terhadap keberadaan Tuhan. Tiap agama yang ada di dunia memiliki karakteristik yang berbeda mengenai hal-hal yang berkaitan dengan kepercayaan dan keyakinan sesuai dengan prinsip yang mereka pegang teguh. Keyakinan tersebut juga mempengaruhi seseorang individu untuk menilai sesuatu yang ada sesuai dengan apa yang diyakininya. Contoh, pandangan seorang Muslim mengenai suatu penyakit tentunya berbeda dengan persepsi seorang Budha. Semua itu tergantung konsep spiritual yang dipahami sesuai dengan keyakinan dan keimanan seorang individu.

Dimensi spiritual berupaya untuk mempertahankan keharmonisan atau keselarasan dengan dunia luar, berjuang untuk menjawab atau mendapatkan kekuatan ketika sedang menghadapi stress emosional,

${ }^{19}$ Syamsu Yusuf, Mental hygiene perkembangan Kesehatan Mental dalam Kajian Psikologi dan Agama, (Bandung: Pustaka Bani Quraisy, 2005), hal 248 
penyakit fisik, atau kematian. Kekuatan timbul diluar kemampuan manusia. Spiritualitas sebagai suatu yang multidimensi, yaitu dimensi eksistensial dan dimensi agama. Dimensi eksistensial berfokus pada tujuan dan arti kehidupan, sedangkan dimensi agama lebih berfokus pada hubungan seseorang dengan Tuhan Yang Maha Penguasa. Spiritualitas juga bisa dilihat sebagai konsep dua dimensi yaitu dimensi vertikal dan horizontal. Dimensi vertikal adalah hubungan dengan Tuhan Yang Maha Tinggi yang menuntun kehidupan seseorang. Dimensi horizontal adalah hubungan seseorang dengan diri sendiri, dengan orang lain dan dengan lingkungan

Berdasarkan penjelasan di atas, maka spiritual bisa dipahami sebagai potensi yang ada dalam diri manusia berhubungan dengan aspek ajaran agama dan keyakinannya. dengan demikian bisa dirumuskan pengertian problem spiritual adalah suatu permasalahan yang berkaitan dengan potensi manusia tentang ajaran agama dan keyakinannya.

\section{Pengertian Lanjut usia}

Lanjut usia adalah periode penutup rentang hidup seseorang, yaitu suatu periode dimana seseorang telah beranjak jauh dari periode terdahulu (Hurlock, 1998: 380).

Tahap usia lanjut merupakan tahap terjadinya penuaan dan penurunan, yang lebih jelas daripada tahap usia baya. Pada usia lanjut, terjadi penurunan kemampuan fisik aktivitas menurun, sering mengalami gangguan kesehatan, dan mereka cenderung kehilangan semangat. Penuaan merupakan perubahan kumulatif pada makhluk hidup, termasuk tubuh, jaringan dan sel, yang mengalami penurunan kapasitas fungsional. Pada manusia, penuaan dihubungkan dengan perubahan degenerative pada kulit, tulang, jantung, pembuluh darah, paru-paru, saraf dan jaringan tubuh lainnya ${ }^{20}$

Adapun batasan umur lanjut Usia yang dijadikan patokan berbedabeda, umumnya berkisar 60-65 tahun. Beberapa pendapat para ahli tentang batasan usia bagi lanjut usia yang pertama menurut WHO ada empat tahapan yaitu usia pertengahan (middle age) antara 45-59 tahun, usia lanjut (elderly) antara 60-74 tahun, dan usia lanjut tua (old) antara 7590 tahun, serta usia sangat tua (very old) di atas 90 tahun $^{21}$

20 Hasan, Aliyah Purwakania, Psikologi Perkembangan Islami. Jakarta: PT Rajagrafindo Persada, 2006, hal 117

${ }^{21}$ Artinawati, Sri, Asuhan Keperawatan Gerontik. Bogor: Penerbit IN Media, 2014, hal 4 
Sementara Smith dalam Hurlock (1998: 380), membagi lansia dalam tiga kategori yaitu: orang tua muda yaitu yang berusia 65-74 tahun, orang tua-tua yaitu yang berusia 75-84 tahun, orang tua sangat tua yaitu lansia yang berusia 85 keatas. ${ }^{22}$ Menurut Hurlock lanjut usia ada dua tahapan yaitu early old age (usia 60-70 tahun), dan advanced old age (usia >70 tahun).

Di Indonesia, batasan lanjut usia adalah 60 tahun ke atas. Hal ini dipertegas dalam Undang-Undang Nomor 13 Tahun 1998 tentang kesejahteraan lanjut usia pada Bab 1 Pasal 1 Ayat 2.23 Pada tanggal 29 Mei 1996 ditetapkanlah hari lanjut usia pada tanggal 29 yang diterbitkan oleh Departemen Sosial dalam rangka pencananganhari lanjut usia nasional. ${ }^{24}$

Penjelasan tersebut di atas, dapat penulis pahami bahwa lanjut usia (lansia) adalah seseorang yang telah memasuki sebuah usia dan ditandai pula dengan penurunan-penurunan fisik dan psikis. Usia yang penulis jadikan patokan berdasarkan undang-undang yaitu 60 tahun keatas.

\section{Pengertian problem psikospiritual lansia.}

Kesehatan manusia yang meliputi tiga elemen yaitu kesehatan fisik, mental dan kesehatan rohani atau spiritual ${ }^{25}$ terdapat banyak kajian ilmiah menerangkan secara mendalam tentang kesehatan fisik dan mental, namun kajian berkaitan dengan spiritual masih kurang dilakukan.

Telah dijelaskan pengertian problem psikologis dan problem spiritual, berdasarkan pengertian tersebut maka dapat diketahui bahwa pengertian problem psikospiritual memiliki arti berbeda. Pada dasarnya problem psikologi adalah suatu persoalan perilaku, perbuatan atau prosesproses mental dan alam pikiran diri atau orang yang berperilaku yang dirasakan dan menuntut adanya suatu pemecahan masalah. Sedangkan problem spiritual adalah suatu permasalahan yang berkaitan dengan potensi manusia tentang ajaran agama dan keyakinannya.

Ketika dicermati, problem spiritual artinya kondisi seseorang ketika spiritualnya sedang bermasalah atau terganggu. Jika sudah terganggu artinya perlu segera diberikan upaya agar kembali normal. Istilah dalam psikologi dikatakan sebagai kesehatan mental. Kesehatan mental membahas tentang upaya, metode dan prosedur melalui beberapa tahap

22 Santrock, Ohn W, Life Span Development, (Jakarta: Erlangga, 2011), hal 193

${ }^{23}$ Artinawati, Sri, Asuhan Keperawatan Gerontik. Bogor: Penerbit IN Media, 2014, hal 6

24 Departemen Kesehatan,1999:2

25 http://www.who.inten/30 april 2016 
diantaranya adalah relasi ketuhanan (spiritual), dimana seseorang secara terus menerus membangun ritual dengan Tuhannya sehingga melahirkan perasaan-perasaan spiritual dengan Tuhannya ${ }^{26}$. Ary Ginanjar juga memandang spiritual sebagai aspek penting yang mampu memberi kesegaran rohani yang berarti dalam menumbuh kembangkan kesehatan mental. Apabila dicermati penjelasan tersebut, pada dasarnya spiritual merupakan bagian dari kejiwaan atau psikologi seseorang yang berkaitan dengan dimensi ketuhanan. ${ }^{27}$

Adapula konsep psikospiritual Islam yang disandarkan kepada sarjana Islam awal seperti Al-Imam Ghozali.28 Menurut Al-Ghazali manusia terdiri daripada tiga unsur yaitu roh, akal dan nafsu. Al-Ghazali menjelaskan bahwa roh merupakan elemen spiritual yang perlu sentiasa dijaga dan dibersihkan karena unsur tersebut sangat penting untuk kesehatan. Selain itu, manusia juga merupakan individu yang rasional atau individu yang mempunyai akal. Akal dalam konteks ini dikaitkan dengan juga dengan unsur spiritual..$^{29}$

Elemen akal atau rasional dalam manusia merujuk kepada upaya untuk bertutur, pemahaman, tanggungjawab, dan dapat melakukan pertimbangan dan penjelasan. Selain roh, akal, dan nafsu menurut AlGhazali turut merujuk pada spiritual. ${ }^{30}$ Dengan demikian dapat penulis pahami bahwa problem psikopsiritual lansia adalah suatu gejala kejiwaan yang berkaitan dengan dimensi ketuhanan dan merupakan ketidak idealan mental yang terjadi pada lansia.

\section{Indikator problem psikospiritual lansia}

Setiap orang yang memasuki usia lanjut memiliki gangguan psikologis dan spiritual dalam hidupnya. Hal itu wajar terjadi terutama bagi orang yang kurang siap menghadapi perubahan hidup dan kehidupan. Indikator gangguan psikologis menurut $\mathrm{BKKBN}^{31}$ sebagai berikut:

${ }^{26}$ Rajab, Khairunnas, Religius Psikologi,(Yogyakarta: Aswajapressindo, 2011), hal 34

27 Agustian, Ary Ginanjar, Rahasia Sukses Membangkitkan ESQ Power; Sebuah Inner Journey Melalui Ihsan, Jakarta: Arga 2004, hal 142

${ }^{28}$ Hamid, Achir Yani, Bunga Rampai Asuhan Keperawatan Kesehatan Jiwa, Jakarta: Penerbit Buku Kedokteran EGC, 2009, hal 12-15

${ }^{29}$ Hamid, Achir Yani, Bunga Rampai Asuhan Keperawatan Kesehatan Jiwa, Jakarta: Penerbit Buku Kedokteran EGC, 2009, hal 12-15

${ }^{30}$ Hamid, Achir Yani, Bunga Rampai Asuhan Keperawatan Kesehatan Jiwa, Jakarta: Penerbit Buku Kedokteran EGC, 2009, hal 12-15

31 (2012:5-6) 


\section{a. Kecemasan dan ketakutan.}

Perasaan ketidakpastian dalam menghadapi masa depan yang berubah jauh dari pola hidup bisaanya, banyak dialami oleh lansia. Hal itu muncul karena berbagai hal seperti daya tahan tubuh dan fungsi organ tubuh yang menurun, kesibukan kerja dan posisi jabatan yang hilang, kehidupan rumah tangga yang kurang harmonis dan sebagainya ikut mempengaruhi kepribadian seseorang yang memasuki usia lansia. Kekhawatiran sosial takut merasa tersingkir dari lingkungan apalagi ketika aktif suka dihormati dan ditakuti orang (bawahan) karena sikapnya yang arogan, sombong dan kurang komunikatif dengan oranglain. Rasa takut dan cemas ketika memasuki lansia akan menambah potensi terserang penyakit fisik dan psikologis, kecuali orang yang mampu menghadapi perubahan keadaan dengan pegangan sipiritual yang kuat dan mantap. Setiap yang muda akan tua dan setiap yang hidup akan mati. Karena itu persiapkan hidup dihari dan persiapkan diri menghadapi kematian dengan mendekatkan diri kepada Yang Maha Pencipta (Tuhan).

\section{b. Mudah tersinggung dan cenderung emosional.}

Pertambahan umur dan perubahan fisik jasmani, langsung atau tidak langsung akan mempengaruhi kemantapan emosional dan ketabahan spiritual seseorang. Lansia umumnya memiliki kepribadian yang labil, mudah tersinggung, takut kesepian, turun percaya diri, nostalgia dengan masa jaya (lampau) dan merasa pernah berjasa tetapi tidak dihargai orang. Sikap dan emosi tersebut hanya bisa diatasi dengan melakukan introspeksi diri dan mawas diri sekaligus mendekatkan diri kepada Tuhan. Dunia ini adalah tempat hidup dan mengabdikan diri sebagai bekal hidup yang lebih abadi diakherat. Upayanya yaitu dengan mengendalikan emosi dan berusaha melakukan pendekatan diri kepada Tuhan, semoga segala amal perbuatan yang baik diterima dan yang tidak baik diampuni-Nya sebelum kita menemui ajal.

\section{c. Banyak bercerita, berkata dan kurang mau mendengar.}

Salah satu sikap dan perilaku lansia umumnya suka bercerita panjang dan berulang tentang kondisi masalalu yang sukses (nostalgia). Padahal indra utama yang berfungsi ketika lahir adalah pendengaran. Karena itu, lansia perlu melatih diri menjadi pendengar yang baik terhadap cerita dan pengalaman yang lebih muda, sehingga dapat memberikan pandangan dan nasehat kepada yang lebih muda. Banyak berbicara dan 
berkata-kata kemungkinan besar akan banyak melakukan kesalahan termasuk cerita yang ditambah sehingga dapat menjadi fitnah (dosa).

Sedangkan menurut Hurlock ${ }^{32}$, beberapa masalah psikologi lansia antara lain:

a. Kesepian (loneliness), yang dialami oleh lansia pada saat meninggalnya pasangan hidup, terutama bila dirinya saat itu mengalami penurunan status kesehatan seperti menderita penyakit fisik berat, gangguan mobilitas atau gangguan sensorik terutama gangguan pendengaran harus dibedakan antara kesepian dengan hidup sendiri. Banyak lansia hidup sendiri tidak mengalami kesepian karena aktivitas sosialnya tinggi, lansia yang hidup dilingkungan yang beraggota keluarga yang cukup banyak tetapi mengalami kesepian.

b. Duka cita (bereavement), dimana pada periode duka cita ini merupakan periode yang sangat rawan bagi lansia. meninggalnya pasangan hidup, temen dekat, atau bahkan hewan kesayangan bisa meruntuhkan ketahanan kejiwaan yang sudah rapuh dari seorang lansia, yang selanjutnya memicu terjadinya gangguan fisik dan kesehatannya. Adanya perasaan kosong kemudian diikuti dengan ingin menangis dan kemudian suatu periode depresi. Depresi akibat duka cita biasanya bersifat self limiting.

c. Depresi, pada lansia stress lingkungan sering menimbulkan depresi dan puan beradaptasi sudah menurun.

d. Gangguan cemas, terbagi dalam beberapa golongan yaitu fobia, gangguan panik, gangguan cemas umum, gangguan stress setelah trauma dan gangguan obsesif-kompulsif. Pada lansia gangguan cemas merupakan kelanjutan dari dewasa muda dan bisaanya berhubungan dengan sekunder akibat penyakit medis, depresi, efek samping obat atau gejala penghentian mendadak suatu obat.

e. Psikosis pada lansia, dimana terbagi dalam bentuk psikosis bisa terjadi pada lansia, baik sebagai kelanjutan keadaan dari dewasa muda atau yang timbul pada lansia.

f. Parafrenia, merupakan suatu bentuk skizofrenia lanjut yang sering terdapat pada lansia yang ditandai dengan waham (curiga) yang sering lansia merasa tetangganya mencuri barang-barangnya atau tetangga berniat membunuhnya. Parfrenia bisaanya terjadi pada lansia yang terisolasi atau diisolasiatau menarik diri dari kegiatan sosial.

g. Sindroma diagnose, merupakan suatu keadaan dimana lansia menunjukkan penampilan perilaku yang sangat mengganggu. Rumah

32 Hurlock, Elizabeth B, Psikologi Perkembangan, Jakarta: Erlangga, 1980, hal:380 
atau kamar yang kotor serta berbau karena lansia ini sering bermainsmain dengan urin dan fesesnya. Lansia sering menumpuk barangbarangnya dengan tidak teratur. Kondisi ini walaupun kamar sudah dibersihkan dan lansia dimandikan bersih namun dapat berulang kembali.

Selanjutnya problem psikologi bisa diindikasikan dari kematangan kepribadian seseorang. Secara umum Gordon W. Allport dalam Ahyadi ${ }^{33}$ mengemukakan beberapa ciri kematangan kepribadian sebagai berikut:

a. Berkembangnya kebutuhan sosial psikologis, rohaniah dan arah minat yang menuju pada pemuasan ideal dan nilai-nilai sosial. Dapat melibatkan diri pada bermacam-macam aktivitas tanpa mementingkan diri sendiri.

b. Kemampuan mengadakan introspeksi, merefleksikan diri sendiri, memandang diri sendiri secara objektif dan kemampuan untuk mendapatkan pemahaman tentang hidup dan kehidupan.

c. Kepribadian yang matang harus memiliki pandangan hidup keagamaan, kematangan kepribadian tanpa dilandasi agama akan menunjukkan kehidupan yang miskin, kurang bermakna dan mudah goyah.

Berdasarkan pendapat di atas dapat penulis pahami bahwa lansia memiliki kecenderungan yang telah melewati masa kematangan kepribadian dalam psikologisnya. Dengan demikian indikator problem psikologi berdasarkan Gordon W. Allport yang penulis rumuskan adalah sebagai berikut:

a. Tidak berkembangnya kebutuhan sosial psikologis, rohaniah dan arah minat yang menuju pada pemuasan ideal dan nilai-nilai sosial. Tidak dapat melibatkan diri pada bermacam-macam aktivitas dan lebih mementingkan diri sendiri.

b. Tidak memiliki kemampuan mengadakan introspeksi, merefleksikan diri sendiri, dan memandang diri sendiri secara objektif serta tidak mampu untuk mendapatkan pemahaman tentang hidup dan kehidupan.

c. Tidak memiliki pandangan hidup keagamaan, ketika kepribadian seseorang tidak dilandasi agama maka akan menunjukkan kehidupan yang miskin, kurang bermakna dan mudah goyah.

Indikator problem spiritual kemudian dirumuskan dengan melihat indikator spiritual ${ }^{34}$ yaitu hubungan dengan diri sendiri, hubungan dengan alam (harmoni), hubungan dengan orang lain (harmonis atau suportif), dan

33 (2001:38)

34 Hamid, Achir Yani, Bunga Rampai Asuhan Keperawatan Kesehatan Jiwa, Jakarta: Penerbit Buku Kedokteran EGC, 2009, hal 4 
hubungan dengan ketuhanan. Keempat karakteristik tersebut dideskripsikan sebagai berikut:

a. Hubungan dengan diri sendiri (kekuatan dalam atau self-reliance) meliputi pengetahuan diri (siapa dirinya, apa yang dapat dilakukannya) dan sikap percaya pada diri sendiri, percaya pada kehidupan/masa depan, ketenangan pikiran, harmoni atau keselarasan dengan diri sendiri.

b. Hubungan dengan alam (harmoni) meliputi: mengetahui tentang tanaman, pohon, margasatwa, iklim dan berkomunikasi dengan alam (bertanam, berjalan kaki), mengabadikan dan melindungi alam.

c. Hubungan dengan orang lain (harmonis atau suportif) meliputi: berbagi waktu, pengetahuan dan sumber secara timbal balik, mengasuh anak, orang tua dan orang sakit, serta meyakini kehidupan dan kematian (mengunjungi, melayat dan lain-lain), dikatakan tidak harmonis apabila: konflik dengan orang lain, resolusi yang menimbulkan ketidakharmonisan dan friksi.

d. Hubungan dengan ketuhanan meliputi: sembahyang atau berdoa atau meditasi, perlengkapan keagamaan, dan lain-lain. Kondisi spiritual yang berhubungan dengan tuhan ini berkaitan dengan kesadaran beragama para lansia. Ada beberapa fokus penelitan yang berkaitan dengan hubungan ketuhanan sebagai berikut: kebutuhan akan kepercayaan dasar, kesadaran beragama yang senantiasa terus menerus diulang untuk membangkitkan kesadaran bahwa hidup adalah ibadah, kebutuhan akan makna hidup, kebutuhan akan komitmen peribadatan dan hubungannya dalam hidup keseharian, kebutuhan akan pengisian keimanan dengan selalu secara teratur mengadakan hubungan dengan Tuhan.

Problem spiritual juga dapat berkaitan dengan masalah spiritual menurut North American Nursing Diagnosis Association dapat disebut dengan distress spiritual ${ }^{35}$. Distres spiritual adalah kerusakan kemampuan dalam mengalami dan mengintegrasikan arti dan tujuan hidup seseorang dihubungkan dengan agama, orang lain, seni, musik, literature, alam, atau kekuatan yang lebih besar dari dirinya. ${ }^{36}$ Mengacu pada pendapat ini, maka masalah spiritual seseorang berkaitan dengan terganggunya dimensi ketuhanan dalam dirinya.

Berdasarkan penjelasan di atas, maka dapat dirumuskan bahwa indikator problem spiritual bisa mengacu pada indikator-indikator distress

35 (Faizah, 2006:26)

36 (Faizah, 2006:26) 
spiritual. Indikator tersebut salah satunya dirumuskan oleh Nanda ${ }^{37}$ sebagai berikut:

1. Berhubungan dengan diri, berkaitan dengan arti dan tujuan hidup, kedamaian, penerimaan, cinta, memaafkan diri, dan keberanian. Kemudian marah, rasa bersalah, dan koping buruk. Hubungan dengan diri sendiri yang meliputi pengetahuan diri (siapa dirinya, apa yang dapat dilakukannya) dan sikap percaya pada diri sendiri, percaya pada kehidupan/masa depan, ketenangan pikiran, harmoni atau keselarasan dengan diri sendiri, seharusnya dapat direalisasikan dengan kehidupan lansia yang berada di balai. Namun hubungan dengan diri sendiri tersebut bertolak belakang dengan apa yang terjadi di Bapelsos tersebut, mayoritas lansia memiliki masalah dengan dirinya, terutama ketenangan pikiran di masa tuanya.

2. Berhubungan dengan orang lain, meliputi: menolak berinteraksi dengan pemimpin agama, menolak berinteraksi dengan teman dan keluarga, mengungkapkan terpisah dari sistem dukungan, merasa terasingkan.

3. Berhubungan dengan seni, musik, literatur dan alam, meliputi: tidak mampu mengekspresikan kondisi kreatif (bernyanyi, mendengar/ menulis musik), tidak ada ketertarikan kepada alam, dan tidak ada ketertarikan kepada bacaan agama.

4. Berhubungan dengan kekuatan yang melebihi dirinya, meliputi; tidak mampu ibadah, tidak mampu berpartisipasi dalam aktifitas agama, merasa ditinggalkan atau marah kepada Tuhan, tidak mampu untuk mengalami transenden, meminta untuk bertemu pemimpin agama, perubahan mendadak dalam praktek keagamaan, tidak mampu introspeksidan mengalami penderitaan tanpa harapan.

Selain itu, North American Nursing Diagnosis Association ${ }^{38}$ juga menegaskan faktor yang berhubungan dari diagnosa distress spiritual adalah; mengasingkan diri, kesendirian atau pengasingan sosial, cemas, deprivasi/kurang sosiokultural, kematian dan sekarat diri atau orang lain, nyeri, perubahan hidup, dan penyakit kronis diri atau orang lain.

Berdasarkan pada item-item tersebut, maka dalam penulisan ini penulis menggunakan indikator problem psikologi lansia yang telah dirumuskan oleh BKKBN ${ }^{39}$ yaitu:

a. Kecemasan dan ketakutan.

b. Mudah tersinggung dan cenderung emosional.

\footnotetext{
37 (Faizah,2006:27)

38 (Faizah 2006)

39 (2012:5-6)
} 
c. Banyak bercerita, berkata dan kurang mau mendengar.

Sedangkan indikator lain tentang problem spiritual lansia mengacu pada indikator-indikator distress spiritual ${ }^{40}$ yaitu:

a. Kurang dalam pengharapan, arti dan tujuan hidup, kedamaian, penerimaan, cinta, memaafkan diri, dan keberanian.

b. Kemudian marah, memiliki rasa bersalah, dan koping buruk, menolak berinteraksi dengan pemimpin agama, menolak berinteraksi dengan teman dan keluarga.

c. Merasa terasingkan, tidak mampu mengekspresikan kondisi kreatif (bernyanyi, mendengar/menulis musik).

d. Tidak ada ketertarikan kepada alam, dan tidak ada ketertarikan kepada bacaan agama, tidak mampu ibadah, tidak mampu berpartisipasi dalam aktifitas agama, merasa ditinggalkan atau marah kepada Tuhan.

e. Tidak mampu untuk mengalami transenden, meminta untuk bertemu pemimpin agama, perubahan mendadak dalam praktek keagamaan, tidak mampu introspeksidan mengalami penderitaan tanpa harapan.

\section{Bimbingan Penyuluhan Islam}

Bimbingan penyuluhan agama Islam atau disebut dengan kata lain bimbingan keagamaan, merupakan proses pemberian bantuan terhadap individu agar individu dapat mengatasi kesulitan yang dihadapi, membuat pilihan yang bijaksana dalam menyesuaikan diri dan lingkungan, serta dapat membentuk pribadi yang mandiri. Agama merupakan suatu ajaran yang datang dari Tuhan yang berfungsi sebagai pembimbing kehidupan manusia agar mereka hidup bahagia dunia dan akhirat. ${ }^{41}$ Berikut beberapa definisi terkait dengan bimbingan dan penyuluhan agama Islam antara lain: 1. Bimbingan ialah suatu proses pemberian bantuan yang terus menerus dan sistematis dari pembimbing kepada yang dibimbing agar tercapai kemandirian dan perwujudan diri dalam mencapai tingkat perkembangan optimal dan penyesuaian diri dengan lingkungannya ${ }^{42}$

2. Bimbingan adalah bantuan atau pertolongan yang diberikan individu atau sekelompok individu dalam menghindari atau mengatasi kesulitan-kesulitan dalam hidupnya agar individu atau sekelompok individu itu dapat mencapai kesejahteraan hidupnya ${ }^{43}$

\footnotetext{
40 (Faizah, 2006:26)

41 Muabrok, Achmad, Al irsyads an Nafsiy Konseling Agama Teori dan Kasus, Jakarta: Bina Rena Pariwara, 2004, hal 4

42 (Surya, 1988: 12);

43 (Walgito, 1989:4);
} 
3. Bimbingan merupakan suatu proses yang berkesinambungan, bukan kegiatan yang seketika atau kebetulan. Bimbingan merupakan serangkaian tahapan kegiatan yang sistematis dan berencana yang terarah kepada pencapaian tujuan ${ }^{44}$

4. Bimbingan adalah suatu bantuan yang diberikan kepada individu atau sekelompok individu dalam menemukan kemampuan-kemampuannya dan segi-segi kehidupan masyarakat, agar demikian nantinya individu atau sekelompok individu lebih sukses dalam melaksanakan rencanarencana hidupnya ${ }^{45}$

5. Bimbingan berarti memberikan bantuan kepada seseorang atau sekelompok orang yang bersifat psikis (kejiwaan) agar individu atau kelompok dapat menentukan berbagai pilihan secara bijaksana dan dalam menentukan penyesuaian diri terhadap tuntutan-tuntutan hidup. Beberapa tujuan bimbingan yang ingin dicapai antara lain; Membantu individu dalam mencapai kebahagiaan pribadi, Membantu individu dalam mencapai kehidupan yang efektif dan produktif dalam masyarakat, Membantu individu dalam mencapai hidup bersama dengan individu yang lain, Membantu individu dalam mencapai harmoni antara cita-cita dan kemampuan yang dimiliki ${ }^{46}$

6. Menurut Isep Zaenal Arifin penyuluhan adalah suatu proses pemberian bantuan baik kepada individu ataupun kelompok dengan menggunakan metode-metode psikologis agar individu atau kelompok dapat keluar dari masalah dengan kekuatan sendiri, baik secara preventif, kuratif, korektif maupun development ${ }^{47}$

7. Penyuluhan menurut Arifin adalah hubungan timbal balik antara dua individu, dimana yang seorang (penyuluh) berusaha membantu yang lain (klien) untuk mencapai pengertian tentang dirinya sendiri dengan hubungannya dalam masalah yang dihadapi pada saat itu dan mungkin pada waktu yang akan datang. ${ }^{48}$

Berdasarkan uraian tersebut maka dapat penulis pahami bahwa bimbingan dan penyuluhan Islam adalah suatu proses pemberian bantuan yang terarah dan berkelanjutan dengan cara memberikan informasi yang telah ditetapkan sebagai hukum agama Islam yaitu Al-Quran dan sunnah

44 Yusuf, Syamsul, Mental Hygiene Perkembangan Kesehatan Mental dalam Kajian Psikologi Agama, Bandung: Pustakan Bani Quraisy, 2005, hal 6

45 Departemen Agama RI, Buku Panduan Pelaksanaan Tugas Penyuluh Agama Utama, Jakarta: Departemen Agama, 2003 hal14

46 (Amin, 2010:38-39).

47 Arifin, Isep Zaenal, Bimbingan Penyuluhan Islam, Jakarta: PT Rajagrafindo Persada, 2009, hal 50

48 (Walgito, 1989: 5) 
yang bertujuan memberikan motivasi untuk terus bersemangat menjalani kehidupan hingga mencapai kesejahteraan di usia akhir.

Bimbingan dan penyuluhan Islam dimaksud adalah kegiatan yang dilakukan oleh penyuluh agama atau pembimbing agama kepada seseorang yang mengalami problem dalam hidupnya agar orang tersebut mampu mengatasinya masalah keagamaannya secara mandiri. Tidak jauh berbeda dari pengertian tersebut yaitu pengertian bimbingan konseling agama yang disampaikan oleh Mubarok yaitu merupakan bantuan yang diberikan kepada seseorang atau kelompok orang yang sedang mengalami kesulitah lahir dan batin dalam menjalankan tugas-tugas hidupnya dengan menggunakan pendekatan agama, yakni dengan membangkitkan kekuatan getaran iman didalam dirinya untuk mendorongnya mengatasi masalah yang dihadapi. ${ }^{49}$

Kemudian dapat dirumuskan bahwa bimbingan dan penyuluhan agama yang akan diberikan kepada seseorang yang memiliki problem psikospiritual memiliki makna yang sama dengan bimbingan konseling agama. Lebih merupakan kegiatan pemberian bimbingan dan penerangan agama kepada masyarakat khususnya dalam artikelini adalah lansia dengan tujuan adanya peningkatan keberagamaan secara total baik pengetahuan, pemahaman dan pengalamannya.

\section{Upaya Penanganan Atas Problem Psikospiritual Lansia}

Manusia adalah mahluk unik yang utuh menyeluruh, yang terdiri atas aspek fisik, psikologis, sosial, kultural dan spiritual. Tidak terpenuhinya kebutuhan manusia pada salah satu diantara dimensi tersebut akan menyebabkan ketidaksejahteraan atau keadaan tidak sehat. Kondisi tersebut dapat dipahami mengingat dimensi fisik, psikologis, sosial, spiritual, dan kultural atau dimensi body, main dan spirit merupakan satu kesatuan yang utuh. Tiap bagian dari individu tersebut tidaklah akan mencapai kesejahteraan tanpa keseluruhan bagian tersebut.

Secara fitrahnya manusia adalah makhluk sosial yang memerlukan orang lain dalam kehidupannya, tanpa sesamanya manusia tidak akan bisa hidup. Ketika terjadi masalah dalam kehidupan maka salah satu cara agar masalah tersebut selesai adalah mencari solusi, meskipun terkadang usaha untuk mengatasi masalah tidak maksimal.

Problem psikospiritual merupakan bagian dari hambatan dimensi menuju kesejahteraan, terutama bagi lansia yang secara fisik, psikologis,

${ }^{49}$ Muabrok, Achmad, Al irsyads an Nafsiy Konseling Agama Teori dan Kasus, Jakarta: Bina Rena Pariwara, 2004, hal 5 
dan spiritual mengalami banyak perubahan. Penurunan pada fisik bisaanya ditandai dengan bahu membungkuk dan tampak mengecil, perut membesar dan tampak membuncit, pinggul tampak menggendor dan tampak lebih besar, garis pinggang melebar, payudara pada wanita akan mengendor, hidung menjulur lemas, bentuk mulut akan berubah karena hilangnya gigi, mata kelihatan pudar, dagu berlipat dua atau tiga, kulit berkerut dan kering, rambut menipis dan menjadi putih ${ }^{50}$

Sedangkan secara psikologis, ciri-ciri penurunannya adalah kesepian, duka cita (Bereavement), depresi, gangguan cemas, parafrenia, dan sindroma diogenes ${ }^{51}$ Sedangkan dilihat dari aspek spiritual sebagaimana indikator yang disampaikan oleh Prof. Achir Yani yaitu Hubungan dengan diri sendiri, hubungan dengan alam (harmoni), hubungan dengan orang lain (harmonis atau suportif), hubungan dengan ketuhanan. ${ }^{52}$ Banyaknya penurunan-penurunan ini kemudian masyarakat menganggap lansia itu lemah dan membebankan. ${ }^{53}$ Dari penjelasan tersebut jelas bahwa psikospiritual merupakan salah satu aspek yang ada dalam kehidupan manusia yang menghambat menuju kesejahteraan terutama lansia yang kondisinya semakin menurun dari berbagai aspek.

Terlebih aspek spiritual yang jika tidak dibarengi dengan kebisaaan yang baik di berbagai aspek maka akan ikut menurun. Psikospiritual tersebut akan menjadi sebuah masalah ketika tidak berjalan sebagaimana mestinya. Problem psikospiritual seseorang yang disampaikan oleh NANDA terlihat dari sikap-sikap mengasingkan diri, kesendirian atau pengasingan sosial, cemas, deprivasi/kurang sosiokultural, kematian dan sekarat diri atau orang lain, nyeri, perubahan hidup, dan penyakit kronis diri atau orang lain. 54

Dinamakan problem psikospiritual lansia adalah suatu gejala kejiwaan yang berkaitan dengan dimensi ketuhanan dan merupakan ketidakidealan mental yang terjadi pada lansia. Ketidakidealan haruslah segera ditangani, apalagi diusia yang semakin tua dan berkemungkinan akan segera berakhir masa hidupnya, maka haruslah diberikan bimbingan yang tepat dalam mengatasinya.

Lanjut usia adalah usia yang sangat rentan dalam segala aspek, terlebih aspek spiritual dan sosial karena begitu terlihat kembali kemasa

50 Hurlock, Elizabeth B, Psikologi Perkembangan, Jakarta: Erlangga, 1980, hal 388

${ }^{51}$ Hurlock, Elizabeth B, Psikologi Perkembangan, Jakarta: Erlangga, 1980, hal 388

52 Hamid, Achir Yani, Bunga Rampai Asuhan Keperawatan Kesehatan Jiwa, Jakarta: Penerbit Buku Kedokteran EGC, 2009, hal 4

53 Jalaluddin, Psikologi Agama, Jakarta : PT RajaGrafindo Persada, 1996, hal 97

54 (NANDA dalam Faizah, 2006: 27). 
kanak-kanaknya, semisal ketika diberikan bimbingan agama dengan metode ceramah, maka metode tersebut harus dibuat semenarik mungkin agar lansia tidak mudah bosan. Karena jika dilihat akibat dari metode yang salah digunakan dalam memberikan bimbingan, lansia akan menjadi malas dan tidak mau mengikuti bimbingan agama lagi.

Melihat fenomena yang dihadapi oleh lansia, maka sangat diperlukan pendidikan dan pengajaran tentang ajaran-ajaran agama Islam secara intensif yang kemudian dipelajari, dihayati dan diamalkan oleh lansia dalam kehidupan sehari-hari. Dengan adanya Pendidikan Agama Islam Non Formal, maka akan mengembalikan kesehatan jiwa orang yang gelisah dan bisa menjadi benteng dalam menghadapi goncangan jiwa. ${ }^{55}$

Untuk mengatasi problem lansia tersebut bimbingan penyuluhan Islam dilakukan untuk meningkatkan pengetahuan dan pemahaman diri dan lingkungannya serta mampu mengatasi berbagai permasalahan sehingga dapat mencapai kesejahteraan tersebut. Semakin dekat seseorang kepada Tuhan dan semakin banyak ibadahnya, maka akan semakin tentramlah jiwanya. ${ }^{56}$

Bimbingan dan penyuluhan Islam sendiri merupakan suatu upaya pemberian bantuan kepada individu dalam hal ini adalah lansia atau sekelompok lansia dengan cara memberikan informasi yang telah ditetapkan sebagai hukum Al-Quran dan sunnah yang kemudian memberikan motivasi untuk terus bersemangat menjalani kehidupan hingga kesejahteraan usia akhir tercapai.

Bimbingan merupakan salah satu bentuk pelayanan sosial yang diberikan dalam upaya memenuhi kebutuhan Penerima Manfaat (PM). Pemberian bimbingan diberikan sebagai pemenuhan kebutuhan lansia. Tidak hanya itu bimbingan tidak akan terlepas dari penyuluhan yang artinya penerangan. Penerangan penulis artikan sebagai motivasi yang berarti upaya pemberian semangat kepada lansia dalam menjalani kehidupan akhirnya. Penekanan dalam arti penyuluhan, artinya ketika seorang pembimbing memberikan bimbingan dia akan mampu memberikan semangat ataupun motivasi kepada PM dalam menjalani kehidupan. Dari itu bimbingan dan pemberian penerangan atau penyuluhan adalah salah satu cara memberikan solusi dalam membantu seseorang mencapai derajat kesejahteraan.

Bimbingan penyuluhan dapat menjadi solusi dalam mengatasi problem psikospiritual lansia. Ketika kita membicarakan tentang

55 (Darajat, 1982 78-79).

56 (Darajat, 1982:79). 
bimbingan spiritual, maka ada berbagai macam yang dikaitkan dengan spiritual sesuai dengan kebutuhan pula. Dalam pemberian pelayanan keagamaan, bimbingan spiritual diarahkan untuk meningkatkan pemahaman dan pengetahuan mengenai agama. Bimbingan diberikan dengan unsur pemenuhan kebutuhan spiritual lansia. Secara umum ada 10 butir kebutuhan dasar spiritual sebagaimana yang disampaikan oleh Dadang Hawari sebagai berikut ${ }^{57}$ :

a. Kebutuhan akan kepercayaan dasar yang senantiasa diulang untuk membangkitkan kesadaran bahwa hidup adalah ibadah

b. Kebutuhan akan makna hidup, tujuan hidup dalam membangun hubungan yang selaras dengan Tuhan dan dengan alam sekitar

c. Kebutuhan akan komitmen peribadatan dan hubungannya dalam hidup keseharian. Banyak pemeluk agama yang hanya melakukan ibadah sebatas ritual, maka mereka kehilangan hikmah dalam menjalankan kehidupan bermasyarakat

d. Kebutuhan akan pengisian keimanan. Dengan cara teratur mengadakan hubungan dengan Tuhan

e. Kebutuhan akan bebas dari rasa bersalah dan berdosa yang merupakan beban mental bagi seseorang

f. Kebutuhan akan penerimaan diri dan harga diri. Setiap orang tentunya ingin diterima dan dihargai oleh lingkungan, tidak dilecehkan ataupun di pinggirkan

g. Kebutuhan akan rasa aman, dan terjamin atas keselamatan terhadap harapan masa depan.

h. Kebutuhan akan tercapainya derajat dan martabat yang semakin tinggi sebagai pribadi yang utuh.

i. Kebutuhan akan terperiharanya interaksi dengan alam dan sesamanya. Setiap orang pasti akan memerlukan interaksi dengan orang lain, demikian pula dengan lingkungan yaitu menjaga kelestarian dan keamanan.

j. Kebutuhan akan kehidupan bermasyarakat yang syarat dengan nilainilai religious.

Berdasarkan uraian diatas, maka sesungguhnya pemenuhan kebutuhan spiritual memerlukan hubungan interpersonal, oleh karenanya pembimbing adalah orang yang tepat untuk memenuhi kebutuhan spiritual lansia. Pembimbing harus mempunyai pegangan tentang keyakinan

57 Hawari, Dadang, Al-Quran, Ilmu Kedokteran Jiwa dan Kesehatan Jiwa, Yogyakarta: Dhana Bhakti Primayasa, 2000, hal 493-494 
spiritual yang memenuhi kebutuhanya untuk mendapatkan arti dan tujuan hidup, mencintai, dan berhubungan serta pengampunan ${ }^{58}$.

Manusia pada hakikatnya merupakan makhluk multi-dimensi yang berarti terdapat beberapa dimensi dalam diri manusia. Istilah Homo Socius yang diungkapkan oleh Aristoteles yang artinya manusia adalah makhluk sosial menunjukan bahwa manusia memiliki dimensi sosial dalam dirinya. Akan tetapi dalam diri manusia tidak hanya terdapat dimensi sosial saja, terdapat tiga dimensi lagi selain dimensi sosial yang membentuk diri manusia, yaitu dimensi fisik, mental dan spiritual.

Dimensi fisik dalam diri manusia tidak perlu diragukan lagi, manusia memiliki wujud yang nyata, dapat dilihat dan disentuh secara fisik. Dimensi sosial pada manusia seperti yang telah dikatakan oleh Aristoteles, manusia membutuhkan orang lain, kita dapat melihat pada kenyataan bahwa dimanapun manusia berada maka disitulah terdapat sebuah komunitas, manusia tidak bisa hidup seorang diri seumur hidupnya. Dimensi mental pada manusia bisa kita lihat pada kebiasaan manusia yang tidak pernah berhenti belajar, belajar disini bukan dalam arti yang sempit seperti pelajaran sekolah ataupun kuliah, akan tetapi dalam arti yang lebih luas yaitu manusia berkembang dengan belajar dari pengalaman hidup dirinya sendiri maupun orang lain, belajar dari kesalahan hidup.

Dimensi yang terakhir yaitu dimensi spiritual, makna atau arti spiritual disini tidak terbatas hanya pada keagamaan. Kalau kita lihat dari asal katanya, spiritual berasal dari bahasa latin spiritus, yang berarti nafas atau roh, spiritual berarti yang ada hubungannya dengan kerohanian atau kejiwaan. Sebagai manusia, kita tidak dapat melihat ataupun menyentuh roh atau jiwa kita, jelas karena bukan merupakan dimensi fisik. Akan tetapi kita tahu dan dapat merasakan keberadaannya, yaitu hati nurani, yang selama ini dipercaya sebagai suara Tuhan, roh kudus atau ada juga yang mempercayainya sebagai sumber kebenaran sejati.

Masing-masing dari ke-empat dimensi manusia diatas baik secara langsung maupun tidak langsung dapat mempengaruhi kesehatan kita, oleh karena itu kita harus senantiasa menjaga serta mengembangkan ke-empat dimensi tersebut. Sebagai contoh, kelalaian menjaga dimensi fisik seperti tidak berolahraga secara rutin dan pola makan yang tidak teratur dapat membuat kita terkena penyakit. kelalaian dalam dimensi mental, seperti tidak pernah melatih otak kita untuk terus aktif dan berpikir akan memperlemah memori atau daya ingat kita. Begitu juga dengan dimensi

58 (Faizah, 2006:11) 
sosial dan spiritual yang secara tidak langsung memberikan pengaruh buruk pada kesehatan.

Masing-masing dimensi memiliki bagian penting yang perlu kita perhatikan, yaitu nutrisi, latihan, istirahat serta pantangan. Nutrisi merupakan bahan kebutuhan dasar dan wajib bagi semua dimensi. Latihan juga merupakan kebutuhan yang sangat penting, meskipun mempunyai cukup nutrisi akan tetapi kekurangan latihan, juga tidak akan membuat dimensi-dimensi tersebut bertumbuh dan berkembang dengan baik. Istirahat juga tidak kalah pentingnya, terlalu banyak latihan tetapi kurang istirahat juga tidak dapat membuat dimensi kita bertumbuh dengan baik. Yang terakhir adalah pantangan yang harus dihindari agar dimensidimensi tersebut dapat terhindar dari kerusakan.

Perencanaan upaya penanganan melibatkan semua pihak dalam memberikan asuhan tanpa mengesampingkan keluarga. Empati dan kematangan jiwa sangat diperlukan dalam memberikan penanganan, dan komunikasi harus tetap terbuka. Berikut beberapa upaya penanganan yang digunakan dalam mengatasi problem psikospiritual ${ }^{59}$ :

a. Dimensi Fisik

Dimensi Fisik meliputi pemeliharaan tubuh kita secara efektif. Dimensi fisik memiliki nutrisi yang harus di penuhi antara lain dengan air, protein, vitamin, lemak, karbohidrat, serta mineral. Latihannya dengan berolahraga, makan dan minum. Istirahat: relaksasi. Pantangan: latihan yang terlalu berlebihan, makan secara berlebihan, alkohol, rokok serta racun.

Memakan jenis makanan yang tepat, istirahat teratur, relaksasi yang memadai dan berolahrara. Olaharaga adalah salah satu aktivitas berdampak besar namun kebanyakan dari kita tidak melakukannya secara konsisten karena tidak mendesak. Dan karena kita tidak melakukannya, cepat atau lambat kita akan mendapatkan diri kita berhadapan dengan masalah dan krisis kesehatan yang muncul sebagai akibat wajar dari kelalaian kita.

b. Dimensi mental

Dimensi mental: Nutrisi: pengetahuan, informasi, ide, dsb. Latihan: berpikir, belajar, bertukar-pikiran, meng-analisa. Istirahat: tidur. Pantangan: pikiran negatif dan malas.

59 Hamid, Achir Yani, Bunga Rampai Asuhan Keperawatan Kesehatan Jiwa, Jakarta: Penerbit Buku Kedokteran EGC, 2009, hal:132 
c. Dimensi Sosial

Dimensi sosial: Nutrisi: kasih sayang, perhatian, rasa percaya, ketulusan, dsb. Latihan: komunikasi (mendengarkan, bercerita, dsb), kontak fisik (pelukan, sentuhan, dsb). Istirahat: menyendiri atau keheningan. Pantangan: gosip, hawa nafsu, cemburu, pengkhiatanan, melanggar janji, dsb.

d. Dimensi Spiritual

Dimensi spiritual adalah inti anda, pusat anda, tujuan hidup anda, komitmen anda. Dimensi ini memanfaatkan sumber yang mengilhami dan mengangkat semangat anda dan mengikat anda pada kebenaran tanpa batas mengenai semua nilai kemanusiaan.

Dimensi spiritual: Nutrisi: doa, kebijaksanaan, sabda Tuhan. Latihan: berdoa, memaafkan, mempraktekan ritual, berharap, tertawa. Istirahat: bermeditasi. Pantangan: balas dendam, kebencian, dosa, ateis. ${ }^{60}$

Penjelasan tersebut menguatkan bahwa ketika psikospiritual mengalami masalah atau problem maka kebutuhan dasar spiritual dan dimensi pada tubuhnya tidak terpenuhi, atau kesejahteraan tidak tercapai. Dengan demikian kondisi lansia yang menghadapi problem psikospiritual haruslah diberikan upaya penanganannya baik berupa bimbingan dan penyuluhan maupun upaya-upaya lainnya, guna tercapainya kebutuhan tersebut.

\section{E. Penutup}

Berdasarkan hasil analisis diatas tentang problem psikospiritual lansia, maka dapat ditarik kesimpulan dari judul Problem Psikospiritual Lansia dan Solusinya dengan Bimbingan Penyuluhan Islam di Balai Pelayananan Sosial Cepiring Kendal yaitu sebagai berikut:

1. Problem psikologi lansia yang berada dibalai pelayanan sosial Cepiring Kendal yaitu kecemasan dan ketakutan, cenderung emosional, banyak bercerita, kesepian, dukacita dan depresi. Sedangkan problem spiritual yang dialami lansia yaitu kurang dalam pengharapan, memiliki arti dan tujuan hidup yang kurang, menolak berinteraksi dengan tokoh agama, tidak mampu beribadah, tidak mampu berpartisipasi dalam aktifitas agama.

2. Upaya penanganan dalam mengatasi problem psikospiritual lansia dengan perspektif bimbingan penyuluhan Islam menunjukkan bahwa

$60 \mathrm{http}: / /$ www.kompasiana.com/antonijuneadi/keseimbangan-antarakeempatdimensi-dalam-diri-manusia: diunduh 26 juli 2016 
pelaksanaan bimbingan penyuluhan Islam secara umum telah menjadi sesuai dengan teori tujuan dan fungsi bimbingan penyuluhan Islam yaitu menjadi pendorong (motivator) bagi lansia sehingga timbul semangat dalam menjalani hari akhir kehidupan, menjadi penggerak untuk mencapai tujuan yaitu ketenangan di hari akhir, serta menjadi pengarah bagi pelaksanaan program bimbingan. meskipun belum dikatakan maksimal menurut penulis karena kendala-kendala dilihat dari unsur-unsur bimbingan.

3. Upaya penanganan yang di lihat dari dimensi fisik yaitu pelatihan rebana, dan berolahraga. Dimensi mental dengan latihan membuat kerajinan, dimensi social dengan latihan komunikasi (mendengarkan, bercerita, dsb), kontak fisik (pelukan, sentuhan, dsb). Dimensi Spiritual adalah pusat tujuan hidup dan komitmen. Latihannya adalah berdoa, memaafkan, mempraktekan ritual, berharap, tertawa. Istirahat: bermeditasi. 


\section{DAFTAR PUSTAKA}

Agustian, Ary Ginanjar, Rahasia Sukses Membangkitkan ESQ Power; Sebuah Inner Journey Melalui Ihsan, Jakarta: Arga 2004

Arifin, Isep Zaenal, Bimbingan Penyuluhan Islam, Jakarta: PT Rajagrafindo Persada, 2009

Artinawati, Sri, Asuhan Keperawatan Gerontik. Bogor: Penerbit IN Media, 2014

Departemen Agama RI, Buku Panduan Pelaksanaan Tugas Penyuluh Agama Utama, Jakarta: Departemen Agama RI, 2003

Departemen Agama RI, Pedoman Pembentukan Kelompok Sasaran Penyuluh Agama Islam, Jakarta: Departemen Agama RI, 2002

Hamid, Achir Yani, Bunga Rampai Asuhan Keperawatan Kesehatan Jiwa, Jakarta: Penerbit Buku Kedokteran EGC, 2009

Hasan, Aliyah Purwakania, Psikologi Perkembangan Islami. Jakarta: PT Rajagrafindo Persada, 2006

Hawari, Dadang, Al-Quran, Ilmu Kedokteran Jiwa dan Kesehatan Jiwa, Yogyakarta: Dhana Bhakti Primayasa, 2000.

Hawari, Dadang, Edisi Manajemen Stress, Cemas dan Depresi, Jakarta: Balai Penerbit FKUI, 2006

Hidayanti, Ema, Dimensi Spiritual dalam Praktek Konseling bagi Penderita HIV/AIDS, Semarang: LP2M IAIN Walisongo, 2012

Hidayanti, Ema, Model Bimbingan Mental Spiritual. Semarang: LP2M IAIN Walisongo, 2014

Hurlock, Elizabeth B, Psikologi Perkembangan, Jakarta: Erlangga, 1980

Jalaluddin, Psikologi Agama, Jakarta : PT RajaGrafindo Persada, 1996

Machasin, Religiusitas, Harapan Hidup dan Design Dakwah pada Lansia Binaan Majelis Ta'lim di Kota Semarang, Penelitian Individual Semarang: LP2M IAIN Walisongo, 2013

Muabrok, Achmad, Al irsyads an Nafsiy Konseling Agama Teori dan Kasus, Jakarta: Bina Rena Pariwara, 2004

Mujahidullah, Khalid, Keperawatan Gereatrik, Celeban Timur : Pustaka Pelajar, 2012 
Mushfir, Konseling Terapi, Jakarta: Gema Insani Press, 2005

Rahmat, Jalaluddin, Psikologi Agama Sebuah Pengantar, Bandung: PT Mizan Pustaka, 2003

Rajab, Khairunnas, Religius Psikologi,Yogyakarta: Aswajapressindo, 2011

Rakhmat, Jalaluddin, Psikologi Komunikasi. Bandung: PT. Remaja Rosdakarya, 2008

Santrock, Ohn W, Life Span Development, Jakarta: Erlangga, 2011

Semiun, Yustinus, Kesehatan Mental, Yogyakarta: Kanius, 2006

Shaleh, Abdurrahman \& Wahab Muhbib Abdul, Psikologi Suatu Pengantar,Jakarta: Kencana, 2004

Sholeh, Moh \& Musbikin Imam, Agama Sebagai Terapi. Celeban Timur: Pustaka Pelajar, 2005

Sururin, Ilmu Jiwa Agama, Jakarta: PT Raja Grafindo, 2004

Syamsu Yusuf, Mental hygiene perkembangan Kesehatan Mental dalam Kajian Psikologi dan Agama, Bandung: Pustaka Bani Quraisy, 2005

Touless, Robert,H, An Introduction Psychology of Religion, alih bahasa Mahnun Husain, Pengantar Psikologi Agama, (Jakarta: RajaGrafindo, cet.II,1993).

Yusuf LN, Syamsu. Mental Hygiene Pengembangan Kesehatan Mental dalam Kajian Psikologi dan Agama. Bandung : Pustaka Bani Quraisy.2004

Noor Shakirah Mat Akhir, Al-Ghazālī and His Story About Soul: A Comparative Study (Pulau Pinang: Penebit Universiti Sains Malaysia, 2008.

Ali, Jeco. Psikologi pada lansia. Http://alijeco.blogspot.com/2008/05/ psikologi-pada-lansia.html diunduh tanggal 8 april 2012

Journal of Social Work in End-of-Life \& Palliative Care, 9:226-240, 2013 